\title{
Effect of Doping Phosphorescent Material and Annealing Treatment on the Performance of Polymer Solar Cells
}

\author{
Zixuan Wang and Fujun Zhang \\ Key Laboratory of Luminescence and Optical Information, Ministry of Education, Beijing Jiaotong University, Beijing 100044, China \\ Correspondence should be addressed to Fujun Zhang; fjzhang@bjtu.edu.cn
}

Received 8 May 2013; Revised 20 June 2013; Accepted 24 June 2013

Academic Editor: Mark van Der Auweraer

Copyright ( 2013 Z. Wang and F. Zhang. This is an open access article distributed under the Creative Commons Attribution License, which permits unrestricted use, distribution, and reproduction in any medium, provided the original work is properly cited.

\begin{abstract}
A series of polymer solar cells (PSCs) with P3HT:PCBM or P3HT:PCBM:Ir(btpy) ${ }_{3}$ blend films as the active layer were fabricated under the same conditions. Effects of phosphorescent material $\operatorname{Ir}(\text { btpy })_{3}$ doping concentration and annealing temperature on the performance of PSCs were investigated. The short-circuit current density $\left(J_{\text {sc }}\right)$ and open-circuit voltage $\left(V_{\text {oc }}\right)$ are increased by adopting P3HT:PCBM:Ir(btpy $)_{3}$ blend films as the active layer when the cells do not undergo annealing treatment. The increased $J_{\mathrm{sc}}$ should be attributed to the increase of photon harvesting induced by doping phosphorescent material $\operatorname{Ir}(\text { btpy })_{3}$ and the effective energy transfer from $\operatorname{Ir}(\text { btpy })_{3}$ to P3HT. The effective energy transfer from $\operatorname{Ir}(\mathrm{btpy})_{3}$ to P3HT was demonstrated by time-resolved photoluminescence (PL) spectra. The increased $V_{\mathrm{oc}}$ is due to the photovoltaic effect between $\operatorname{Ir}(\mathrm{btpy})_{3}$ and PCBM. The power conversion efficiency (PCE) of PSCs with P3HT:PCBM as the active layer is increased from $0.19 \%$ to $1.49 \%$ by annealing treatment at $140^{\circ} \mathrm{C}$ for 10 minutes. The PCE of PSCs with P3HT:PCBM:Ir(btpy $)_{3}$ as the active layer is increased from $0.49 \%$ to $0.95 \%$ by annealing treatment at lower temperature at $100^{\circ} \mathrm{C}$ for 10 minutes.
\end{abstract}

\section{Introduction}

Polymer solar cells (PSCs) are considered one of the most promising sources for clean and renewable energy due to their advantages such as lightweight, low cost, ease of large scale manufacture, and compatibility with flexible substrates [1-4]. Many effective approaches have been carried out to improve the performance and stability of PSCs, such as synthesizing new narrow bandgap materials for better photon harvesting, modifying the interfaces for better charge carrier collection, and applying novel configurations $[5,6]$. But the performance of PSCs is still not satisfactory for commercial use. Factors limiting the PCE of PSCs could be summarized as the following: (i) mismatch between the absorption of organic photovoltaic materials and the solar light spectrum [7]; (ii) the relatively lower exciton dissociation efficiency induced by the limit of exciton diffusion distance and interfacial energy level mismatch $[8,9]$; and (iii) the transport and collection of charge carriers dependence on the phase separation in active layers and the work function of electrode materials $[1,10]$. To strengthen the absorption range and intensity of the active layer, an effective method is to use two kinds of electron donors which have a complementary absorption. Sharma et al. reported that the PCE of PSCs based on P3HT: $\mathrm{PC}_{70} \mathrm{BM}$ as the active layer was improved from $3.23 \%$ to $4.37 \%$ by doping soluble DPP-CN small molecule material [11]. Xu et al. reported that the $V_{\text {oc }}$ of PSCs based on P3HT:PCBM was improved to $0.85 \mathrm{~V}$ by doping poly(9,9-dioctylfluorene-co-bithiophene) (F8T2) into P3HT:PCBM [12]. Molecular arrangement of donor and acceptor materials has great influence on photon harvesting and charge carrier transport and collection, which strongly determines the performance of PSCs. A series of effective methods were proposed to control the molecular arrangement, such as annealing treatment, solvent additive treatment, nanoimprint, and electric field treatment methods [13-16]. Ma et al. reported that the PCE of PSCs with P3HT:PCBM as active layer was improved to $5 \%$ by annealing treatment on the active layer [17]. It is known that only excitons dissociated into free charge carriers can contribute to the performance of PSCs. However, exciton dissociation efficiency is strongly determined by the exciton 
diffusion length $\left(L_{D}\right)$, donor/acceptor interfacial energy barriers, and internal electric field, while $L_{D}$ is mainly determined by two parameters, exciton lifetime $(\tau)$ and mobility $(\mu)[18,19]$. The singlet state photogenerated excitons in donor materials have a very short lifetime, which is less than $1 \mathrm{~ns}$ [20]. If singlet excitons can be transformed into triplet excitons with a longer lifetime through intersystem crossing, this would be beneficial to exciton dissociation. A probable strategy to increase the intersystem crossing efficiency is using heavy atom effects by doping magnetic or phosphorescent materials into organic photovoltaic materials. Phosphorescent materials, such as tris[2(benzo[b] thiophen-2-yl) pyridinato- $\left.\mathrm{C}^{3}, \mathrm{~N}\right]$ iridium (III) ( $\left.\operatorname{Ir}(\text { btpy })_{3}\right)$, bis [2-(4-tertbutylphenyl) benzothiazolato-N, $\mathrm{C}^{2}$ ] iridium (acetylacetonate) $\left((\mathrm{t}-\mathrm{bt})_{2} \operatorname{Ir}(\mathrm{acac})\right), 2,3,7,8,12,13,17,18$ octaethyl-21H,23H-porphyrin platinum (II) (PtOEP), and tris[2-phenylpyridinato] $\operatorname{Ir}(\mathrm{III}) \quad\left(\operatorname{Ir}(\mathrm{ppy})_{3}\right)$ have attracted much attention because of their potential application in PSCs [21-25]. Yu et al. reported that the exciton diffusion distance was increased by doping $(\mathrm{t}-\mathrm{bt})_{2} \operatorname{Ir}(\mathrm{acac})$ into copper phthalocyanine $(\mathrm{CuPc})$ [21]. However, Lee reported that carrier generation in the bulk heterojunction was not enhanced in the presence of PtOEP because the rate and probability of excition dissociation between PtOEP and PCBM are much faster and higher than that of triplet-triplet energy transfer between PtOEP and MEH-PPV [26]. Zhang et al. reported that the PCE of PSCs based on oleic acid$\mathrm{Fe}_{3} \mathrm{O}_{4}$-doped P3HT:PCBM as the active layer was enhanced by $\sim 18 \%$ primarily due to the increase of $J_{\mathrm{sc}}$, which is attributed to the increase of the population of triplet excitons induced by the magnetic field effect originated from the superparamagnetism of $\mathrm{Fe}_{3} \mathrm{O}_{4}$ nanoparticles (NPs) [27].

In this paper, the effect of phosphorescent material $\operatorname{Ir}(\text { btpy })_{3}$ doping concentration in P3HT:PCBM and annealing treatment temperature on performance of PSCs was investigated. For the PSCs with P3HT:PCBM as active layer, the PCE of PSCs arrives to $1.4 \%$ after annealing treatment at $140^{\circ} \mathrm{C}$ for 10 minutes. The PSCs with P3HT:PCBM:Ir(btpy) ${ }_{3}$ as active layer have larger PCE compared to PSCs with P3HT:PCBM as active layer under lower temperature annealing treatment. However, the performance of PSCs with P3HT:PCBM:Ir(btpy) ${ }_{3}$ as active layer was decreased by high temperature annealing treatment. The underlying reason was discussed from the photon harvesting, energy transfer, and phase separation induced by doping phosphorescent material $\operatorname{Ir}(\mathrm{btpy})_{3}$ in P3HT:PCBM.

\section{Experimental Section}

P3HT with an average molecular weight of 48000 and PCBM (both are purchased from Nichem Fine Technology Co., Ltd.) was mixed by 1:0.8 (weight ratio) and dissolved in chloroform with a concentration of $18 \mathrm{mg} / \mathrm{mL}$. Phosphorescent material $\operatorname{Ir}(\mathrm{btpy})_{3}$ (purchased from Jilin OLED Photoelectric materials Co., Ltd.) was dissolved in chloroform with a concentration of $2 \mathrm{mg} / \mathrm{mL}$. The indium tin oxide (ITO) glass substrates (sheet resistance 15 $\Omega / \square$ ) were cleaned consecutively in ultrasonic baths containing acetone, ethanol, and de-ionized water and dried by high pure nitrogen gas. The precleaned ITO substrates were then treated by UV-ozone for $10 \mathrm{~min}$ in order to further clean the substrates and improve the work function of ITO substrates. An ultrathin layer of poly-(3,4-ethylenedioxythiophene)poly-(styrenesulfonate) (PEDOT:PSS) (purchased from H.C. Starck Co., Ltd.) was spin coated on the ITO substrates under $3000 \mathrm{rpm}$ for $40 \mathrm{~s}$. Then, PEDOT:PSS-coated ITO substrates were dried in air at $120^{\circ} \mathrm{C}$ for $10 \mathrm{~min}$. The active layers were prepared by spin-coating method under $2000 \mathrm{rpm}$ for $40 \mathrm{~s}$. An aluminum cathode layer of about $100 \mathrm{~nm}$ was deposited on the active layer under $10^{-4}$ pa vacuum conditions. The active area is about $10 \mathrm{~mm}^{2}$, which is defined by the overlap of ITO anode and $\mathrm{Al}$ cathode.

The structure configuration of PSCs is ITO/PEDOT:PSS/ P3HT:PCBM:Ir(btpy) ${ }_{3}$ or P3HT:PCBM/Al. Parts of fabricated cells were carried out with annealing treatments under different temperature in the room conditions. The absorption spectra of films were measured with a Shimadzu UV-3101 PC spectrometer. The photoluminescence (PL) spectra were measured with a LS-55 spectrometer from Perkin Elmer. The current-voltage characteristics of PSCs were measured using a Keithley 4200 semiconductor characterization system and ABET Sun 2000 solar simulator. Time-resolved transient PL spectra were measured using FluoroCube-01NL and FluoroHub-NL from Jobin Yvon. The schematic structure configuration of PSCs and chemical structures of used organic materials are shown in Figure 1.

\section{Results and Discussion}

The P3HT, Ir(btpy) ${ }_{3}$, P3HT:PCBM, and P3HT:PCBM: $\operatorname{Ir}(\text { btpy })_{3}$ films were prepared on quartz substrates under the same condition; the absorption spectra of all films are shown in Figure 2. Neat P3HT films show a large absorption range from $400 \mathrm{~nm}$ to $600 \mathrm{~nm}$. Neat $\operatorname{Ir}(\text { btpy })_{3}$ films have strong absorption from UV-zone to $500 \mathrm{~nm}$. The absorption spectra of neat P3HT, PCBM, and $\operatorname{Ir}(\text { btpy })_{3}$ films have an apparent spectral overlapping in the range of $400 \mathrm{~nm}-500 \mathrm{~nm}$. Doping $\operatorname{Ir}(\mathrm{btpy})_{3}$ can also strengthen the relatively weak area in P3HT:PCBM absorption at $360-430 \mathrm{~nm}$, where both P3HT and PCBM have a weak absorption at this range. Therefore, their blend films could harvest more photon to produce more photo-generated excitons. It is obvious that the absorption intensity of P3HT:PCBM:Ir(btpy) ${ }_{3}$ films is bigger than that of P3HT:PCBM films in the visible light range, which is beneficial to increase the performance of PSCs. It is known that photon harvesting in the active layer is the key issue to improve the PCE of PSCs [28]. Phosphorescent material $\operatorname{Ir}(\text { btpy })_{3}$ has long exciton lifetime on the triplet states due to the heavy atom effect [22]. Figure 3 shows the PL spectra of $\operatorname{Ir}(\text { btpy })_{3}$, P3HT, and P3HT:Ir(btpy) $)_{3}(100: 1)$ films under the excitation of $410 \mathrm{~nm}$ light. The PL spectra of $\operatorname{Ir}(\mathrm{btpy})_{3}$ films show two emission peaks at $596 \mathrm{~nm}$ and $648 \mathrm{~nm}$, which has an apparent spectral overlapping with the absorption spectrum of P3HT. According to the mechanism of energy transfer between organic materials, the energy transfer from $\operatorname{Ir}(\text { btpy })_{3}$ to P3HT may occur due to their large spectral 

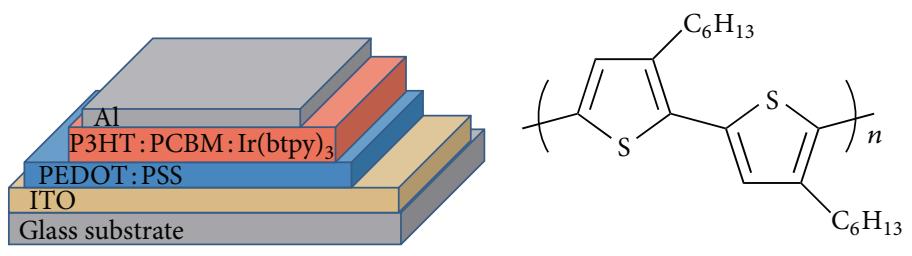

P3HT

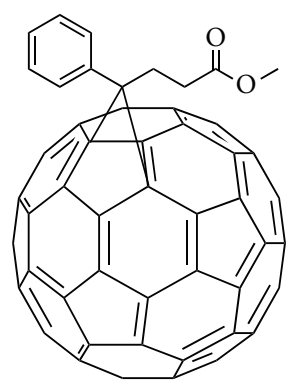

$\mathrm{PC}_{60} \mathrm{BM}$

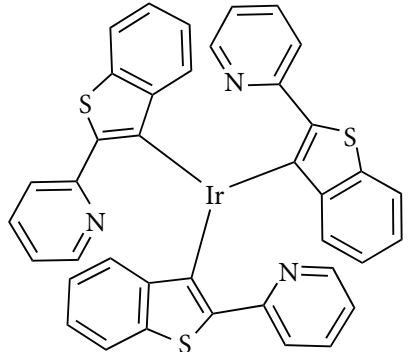

$\operatorname{Ir}(\text { btpy })_{3}$

FIGURE 1: Schematic structure configuration of PSCs and chemical structures of used organic materials.

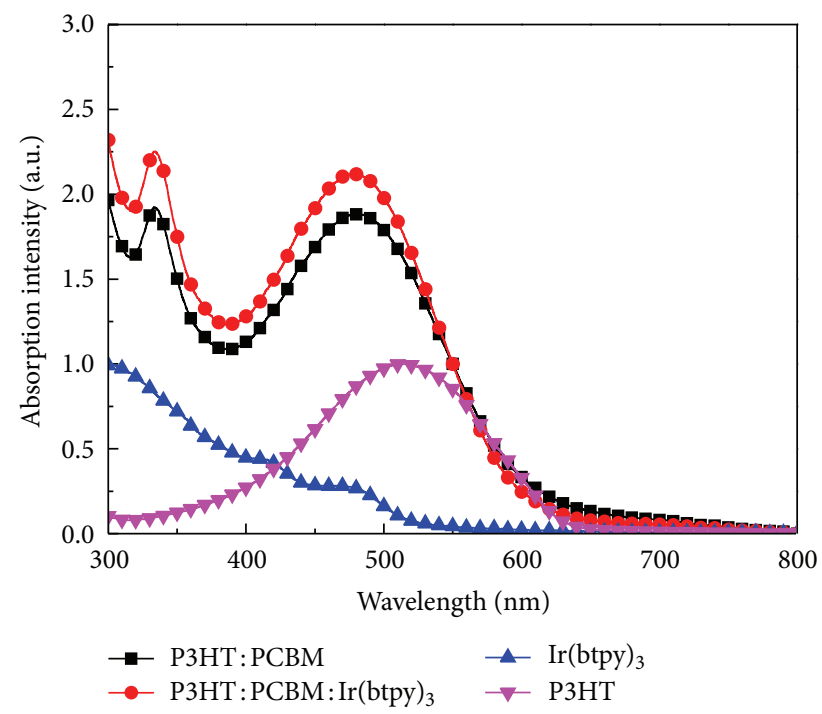

FIgURE 2: Absorption spectra of neat P3HT, neat $\operatorname{Ir}(\text { btpy })_{3}$, P3HT:PCBM, and P3HT:PCBM:Ir(btpy) ${ }_{3}$ films.

overlapping, which could be further demonstrated by the PL spectra of P3HT:Ir(btpy) ${ }_{3}$ blend films [29]. The emission peak at $596 \mathrm{~nm}$ from phosphorescent material Ir(btpy $)_{3}$ could not be observed from PL spectra of P3HT:Ir(btpy $)_{3}(100: 1)$ films. More information about the energy transfer process can be acquired by comparing the intensity ratio of emission peaks representing different exciton states in Figure 3. Polymer P3HT has an emission peak at $654 \mathrm{~nm}$ and another emission peak at $715 \mathrm{~nm}$. The emission intensity ratio of $715 \mathrm{~nm}$ to that of $654 \mathrm{~nm}$ is about 0.90 . It is very interesting that the emission intensity ratio of $715 \mathrm{~nm}$ to that of $654 \mathrm{~nm}$ was increased to 3.23 in the P3HT:Ir(btpy $)_{3}(100: 1)$ blend films under the same excitation condition. The relative increased emission intensity of $715 \mathrm{~nm}$ should be attributed to the energy transfer from the triplet states of $\operatorname{Ir}(\mathrm{btpy})_{3}$ to the lower energy level of P3HT. To further confirm these phenomena, PL spectra of films prepared by different doping concentration P3HT:Ir(btpy) ${ }_{3}$ solutions were measured and are shown in Figure 4.

The quench of emission peak at $596 \mathrm{~nm}$ could be observed from PL spectra of all blend films with different doping

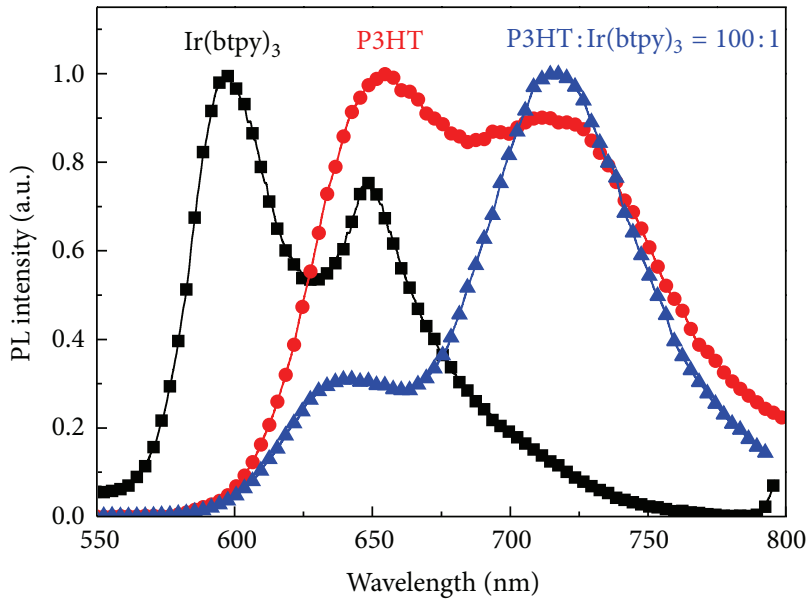

Figure 3: PL spectra of $\operatorname{Ir}(\text { btpy })_{3}$, P3HT, and P3HT:Ir(btpy $)_{3}$ films under the excitation of $410 \mathrm{~nm}$ light.

concentrations, which indicated that the energy transfer from $\operatorname{Ir}(\text { btpy })_{3}$ to P3HT maintains high efficiency, as shown in Figure 4. Another interesting phenomenon is that the longer wavelength emission peak in the PL spectra of blend films undergoes a gradually blueshift along with the increase of doping concentration, resulting in only one broad emission peak at $676 \mathrm{~nm}$ for blend films with $8 \% \operatorname{Ir}(\text { btpy })_{3}$ doping concentration. Compared with the obvious and rapid change of emission intensity at $654 \mathrm{~nm}$ in blend films, the blueshift of emission at $715 \mathrm{~nm}$ has concentration dependence. Since the radiation recombination from the lower energy level of $\mathrm{P} 3 \mathrm{HT}$ to the ground state corresponds to the $715 \mathrm{~nm}$ emission, it is reasonable to believe that $\operatorname{Ir}(\text { btpy })_{3}$ has different effect to excitons on different energy levels. Zeng et al. reported that the external heavy atom effect has a relatively stronger influence on the $S_{1}-T_{1}$ nonradiative transitions than on the $\mathrm{T}_{1}-\mathrm{S}_{0}$ radiative transitions [30]. Therefore, another reason for the increase of emission intensity ratio of $715 \mathrm{~nm}$ to that of $654 \mathrm{~nm}$ may be the heavy metal effect on singlet-triplet intersystem transfer. The phosphorescent material $\operatorname{Ir}(\mathrm{btpy})_{3}$ might enhance the efficiency of singlet-triplet intersystem crossing of P3HT excitons, resulting in the increase of $715 \mathrm{~nm}$ emission intensity. 


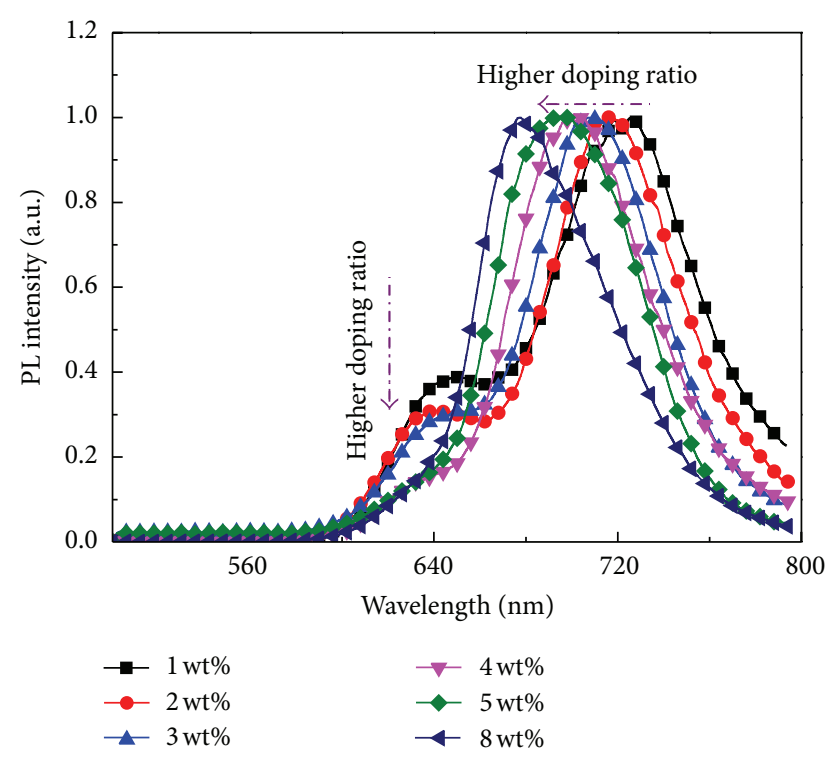

Figure 4: PL spectra of P3HT:Ir(btpy) ${ }_{3}$ films with different doping ratio under the excitation of $410 \mathrm{~nm}$ light.

In order to confirm the energy transfer from $\operatorname{Ir}(\text { btpy })_{3}$ to P3HT, time-resolved transient PL spectra of neat P3HT, $\operatorname{Ir}(\text { btpy })_{3}$, and P3HT:Ir(btpy $)_{3}$ blend films were measured under the excitation of $460 \mathrm{~nm}$ light and are shown in Figure 5. The inset image of Figure 5 is time-resolved transient PL spectrum of $\operatorname{Ir}(\text { btpy })_{3}$ films by monitoring $650 \mathrm{~nm}$ emission. The emission lifetime of $\operatorname{Ir}(\text { btpy })_{3}$ is $\sim 4.21$ us, which is thousands of times longer than that of P3HT singlet state emission lifetime [22]. The lifetime of emission peak at $650 \mathrm{~nm}$ is increased from $~ 700$ ps of neat P3HT films to 1.05 ns of P3HT: $\operatorname{Ir}(\text { btpy })_{3}$ films, which should be induced by the energy transfer process from $\operatorname{Ir}(\mathrm{btpy})_{3}$ to P3HT.

A series of PSCs with P3HT:PCBM or different $\operatorname{Ir}(\text { btpy })_{3}$ doping concentrations in P3HT:PCBM as the active layer were fabricated under the same preparation conditions, and the $J-V$ characteristics of PSCs were measured under illumination intensity of $100 \mathrm{~mW} / \mathrm{cm}^{2}$, as shown in Figure 6 . It is apparent that $J_{\mathrm{sc}}$ is increased from $0.96 \mathrm{~mA} / \mathrm{cm}^{2}$ to $1.74 \mathrm{~mA} / \mathrm{cm}^{2}$ along with the increase of $\operatorname{Ir}(\text { btpy })_{3}$ doping concentration, which could be supported by the increased absorption intensity of P3HT:PCBM:Ir(btpy $)_{3}$ films compared with P3HT:PCBM and energy transfer from $\operatorname{Ir}(\text { btpy })_{3}$ to P3HT. The PL emission of $\operatorname{Ir}(\mathrm{btpy})_{3}$ molecules could be totally quenched by doping lower concentration PCBM (not shown), which means that photo-generated excitons on $\operatorname{Ir}(\text { btpy })_{3}$ could be dissociated into free charge carriers by PCBM, resulting in the product of photovoltaic effect between $\operatorname{Ir}(\text { btpy })_{3}$ and PCBM. It is known that the $V_{\mathrm{oc}}$ of PSCs is determined by the energy difference between the highest occupied molecular orbital (HOMO) of the donor and the lowest unoccupied molecular orbital (LUMO) of the acceptor [31]. Therefore, the increase of $V_{o c}$ should be attributed to the larger bandgap of $\operatorname{Ir}(\text { btpy })_{3}$ compared with P3HT according to their PL and absorption spectra. The $V_{\text {oc }}$ of PSCs arrives to $0.72 \mathrm{~V}$, and PCE arrives to $0.41 \%$ when the

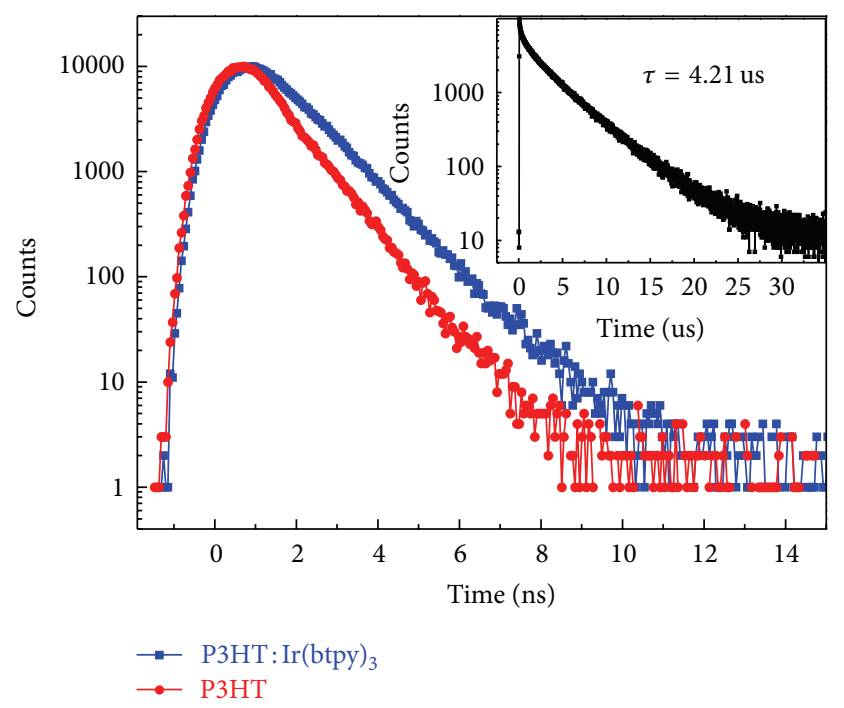

FIgURE 5: Time-resolved transient PL spectra of P3HT and P3HT:Ir(btpy) ${ }_{3}$ films by monitoring $650 \mathrm{~nm}$ under the excitation of $460 \mathrm{~nm}$ light. The inset image is the time-resolved transient PL spectra of $\operatorname{Ir}(\text { btpy })_{3}$ film by monitoring $650 \mathrm{~nm}$.

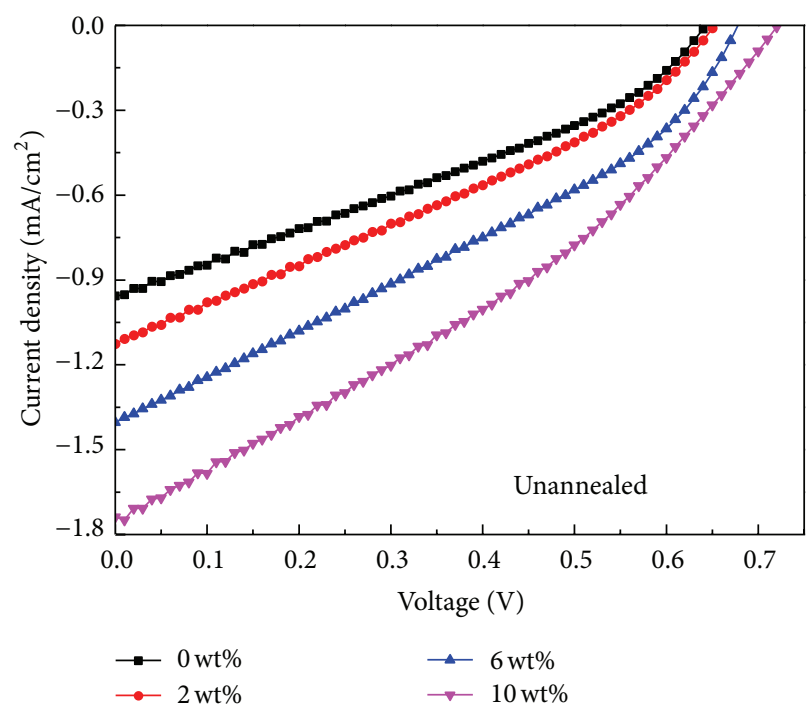

FIGURE 6: Current density versus voltage curves of PSCs with different $\operatorname{Ir}(\text { btpy })_{3}$ doping concentrations under illumination intensity $100 \mathrm{~mW} / \mathrm{cm}^{2}$.

$\operatorname{Ir}(\text { btpy })_{3}$ doping concentration increases to $10 \%$. It is known that the annealing treatment on PSCs is based on P3HT: $\mathrm{PCBM}$ as the active layer has great effect on the performance of cells [32]. In order to improve the performance of PSCs with P3HT:PCBM:Ir(btpy $)_{3}$ as the active layer, a series of annealing treatment on the cells were carried out under different annealing temperatures.

The $J-V$ curves of PSCs with different annealing temperature were measured, and the relationships between PCE and annealing temperature are summarized in Figure 7. The PCE of PSCs with P3HT:PCBM as the active layer was increased 


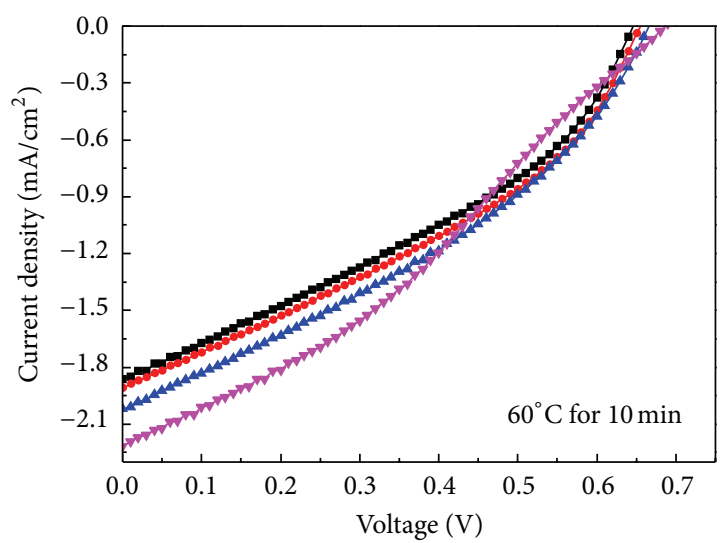

(a)

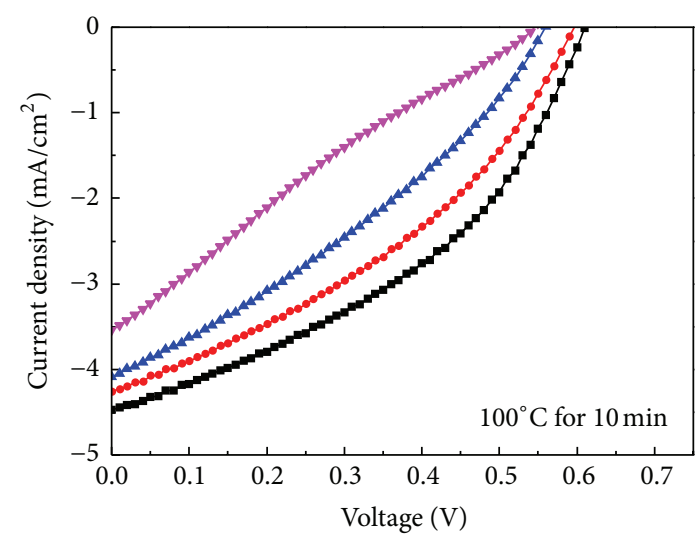

(c)

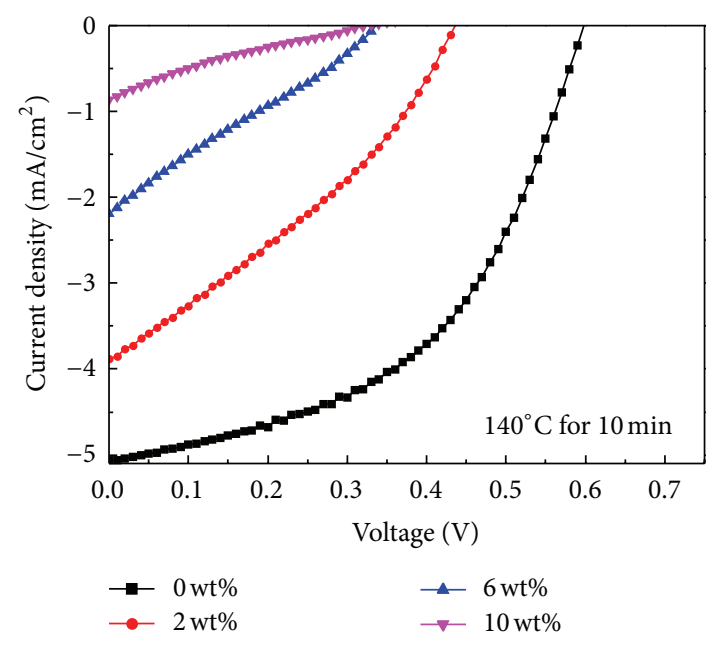

(e)

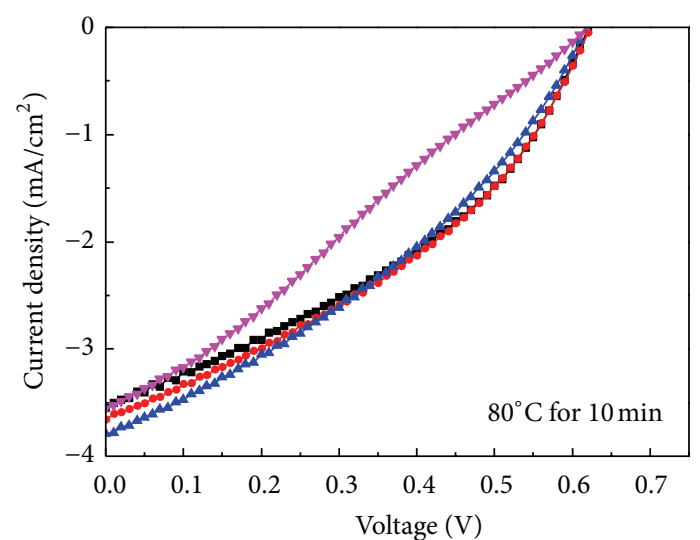

(b)

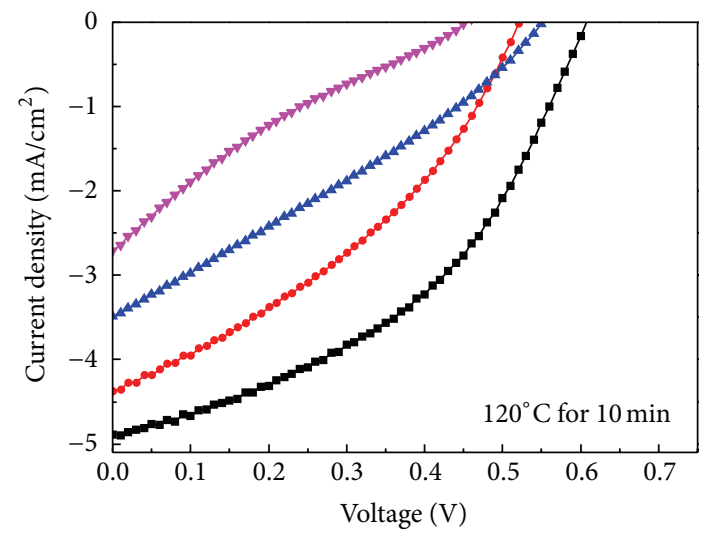

(d)

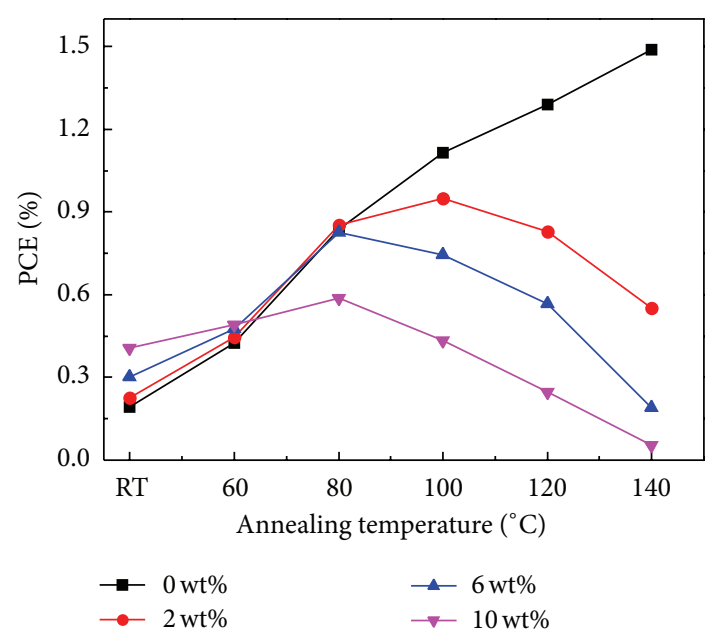

(f)

FIGURE 7: The $J-V$ curves of PSCs under different annealing temperature and the relationship between PCE and annealing temperature.

along with the increase of annealing temperature; the maximum PCE is about $1.49 \%$ when the annealing temperature is $140^{\circ} \mathrm{C}$, which accords with our previous reports $[33,34]$. The effects of annealing treatment on the performance of PSCs could be summarized as the followings: (i) adjust molecular arrangement for enhancing the absorption intensity and range and charge carrier transporting; (ii) increase the interface between donor and acceptor for improving exciton dissociation. However, the process of high temperature annealing treatment on PSCs may increase the fabrication 
cost. It is a great challenge to obtain high performance PSCs without annealing treatment or low temperature annealing treatment.

All the PSCs with ternary blend films as the active layer show the similar relationship between PCE and annealing temperature; the PCE is increased along the increase of annealing temperature and then decreased when the annealing treatment temperature exceed the best value. The PCE of PSCs with $2 \mathrm{wt} \% \operatorname{Ir}(\mathrm{btpy})_{3}$ doping concentration arrives to the maximum value $(0.95 \%)$ under $100^{\circ} \mathrm{C}$ annealing treatment with 10 minutes. The performance decrease trend of PSCs dependence on annealing temperature was more and more apparent along with the increase of $\operatorname{Ir}(\text { btpy })_{3}$ doping concentration. The key parameters of PSCs with ternary blend films as the active layer, including $J_{\mathrm{sc}}, V_{\mathrm{oc}}$, and fill factor, decreased when the annealing treatment temperature goes beyond $100^{\circ} \mathrm{C}$. The underlying reason could be attributed to $\operatorname{Ir}(\text { btpy })_{3}$ molecular aggregation through annealing treatment, which destroys the phase separation and charge carrier transporting microstructure in the active layer. The photovoltaic effect of PSCs with $10 \mathrm{wt} \%$ doping concentration almost could not be observed after $140^{\circ} \mathrm{C}$ annealing treatment, which is lower than this kind of PSCs without annealing treatment. After comprehensive analysis on the effect of doping concentration and annealing temperature on the PSCs performance, the higher $\operatorname{Ir}(\mathrm{btpy})_{3}$ doping concentration is beneficial to photon harvesting in the active layer; however, the interpenetrating network of P3HT:PCBM was damaged by doping $\operatorname{Ir}(\text { btpy })_{3}$ and can be totally destroyed through high temperature annealing treatment. Therefore, adjusting the balance between absorption and phase separation induced by doping phosphorescent material may provide an effective method to improve the PSCs performance.

\section{Conclusion}

A series of PSCs with P3HT:PCBM, doped different concentration $\operatorname{Ir}(\text { btpy })_{3}$ as the active layer were fabricated and measured under the same conditions. The effective energy transfer from Ir(btpy) ${ }_{3}$ to P3HT was demonstrated by absorption, PL, and time-resolved transient PL spectra. The photon harvesting ability of the active layer could be improved by doping $\operatorname{Ir}(\text { btpy })_{3}$ in P3HT:PCBM, which is beneficial to the increase of $J_{\mathrm{sc}}$. The $V_{\mathrm{oc}}$ is also increased, which could be attributed to the photovoltaic effect between $\operatorname{Ir}(\text { btpy })_{3}$ and PCBM. For the PSCs with P3HT:PCBM as the active layer, the PCE is increased along with the annealing temperature and arrives to $1.49 \%$ when the annealing temperature is $140^{\circ} \mathrm{C}$. However, the PCE of PSCs with ternary blend films as the active layer is decreased when the annealing temperature goes beyond $100^{\circ} \mathrm{C}$, which may be due to $\operatorname{Ir}(\mathrm{btpy})_{3}$ molecular aggregation under the higher annealing temperature. The PCE of PSCs with $2 \mathrm{wt} \% \operatorname{Ir}(\text { btpy })_{3}$ doping concentration arrives to $0.95 \%$ under $100^{\circ} \mathrm{C}$ annealing treatment 10 minutes.

\section{Acknowledgments}

The authors express their thanks to the Fundamental Research Funds for the Central Universities (2013JBZ004) and Beijing Natural Science Foundation (2122050); Fujun Zhang thanks the support from the State Key Laboratory of Catalysis and the Key Laboratory of Photochemical Conversion and Optoelectronic Materials, TIPC, CAS.

\section{References}

[1] Y. Zhou, C. Fuentes-Hernandez, J. Shim et al., "A universal method to produce low-work function electrodes for organic electronics," Science, vol. 336, no. 6079, pp. 327-332, 2012.

[2] Z. He, C. Zhong, S. Su, M. Xu, H. Wu, and Y. Cao, "Enhanced power-conversion efficiency in polymer solar cells using an inverted device structure," Nature Photonics, vol. 6, no. 9, pp. 593-597, 2012.

[3] O. Inganäs, "Organic photovoltaics: avoiding indium," Nature Photonics, vol. 5, no. 4, pp. 201-202, 2011.

[4] Z. M. Beiley and M. D. McGehee, "Modeling low cost hybrid tandem photovoltaics with the potential for efficiencies exceeding 20\%," Energy \& Environmental Science, vol. 5, no. 11, pp. 9173-9179, 2012.

[5] F. Zhang, X. Xu, W. Tang et al., "Recent development of the inverted configuration organic solar cells," Solar Energy Materials and Solar Cells, vol. 95, no. 7, pp. 1785-1799, 2011.

[6] M. Graetzel, R. A. J. Janssen, D. B. Mitzi, and E. H. Sargent, "Materials interface engineering for solution-processed photovoltaics," Nature, vol. 488, no. 7411, pp. 304-312, 2012.

[7] L. Bian, E. Zhu, J. Tang, W. Tang, and F. Zhang, "Recent progress in the design of narrow bandgap conjugated polymers for highefficiency organic solar cells," Progress in Polymer Science, vol. 37, no. 9, pp. 1292-1331, 2012.

[8] J. D. Servaites, M. A. Ratner, and T. J. Marks, "Organic solar cells: a new look at traditional models," Energy and Environmental Science, vol. 4, no. 11, pp. 4410-4422, 2011.

[9] T. Stübinger and W. Brütting, "Exciton diffusion and optical interference in organic donor-acceptor photovoltaic cells," Journal of Applied Physics, vol. 90, no. 7, pp. 3632-3641, 2001.

[10] X. Xu, F. Zhang, J. Zhang et al., "High efficient inverted polymer solar cells with different annealing treatment," Materials Science and Engineering C, vol. 32, no. 4, pp. 685-691, 2012.

[11] G. D. Sharma, S. P. Singh, M. S. Roy, and J. A. Mikroyannidis, "Solution processed bulk heterojunction polymer solar cells with low band gap DPP-CN small molecule sensitizer," Organic Electronics, vol. 13, no. 9, pp. 1756-1762, 2012.

[12] X. W. Xu, E. W. Zhu, L. Y. Bian et al., "Luminescent and photovoltaic properties of poly(9,9-dioctylfluorene-co-bithiophene) in organic electronic devices," Chinese Science Bulletin, vol. 57, no. 9, pp. 970-975, 2012.

[13] L. Ye, S. Q. Zhang, W. Ma et al., "from binary to ternary solvent: morphology fine-tuning of D/A blends in pdpp3tbased polymer solar cells," Advanced Materials, vol. 24, no. 47, pp. 6335-6341, 2012.

[14] W. Zeng, K. S. L. Chong, H. Y. Low, E. L. Williams, T. L. Tam, and A. Sellinger, "The use of nanoimprint lithography to improve efficiencies of bilayer organic solar cells based on P3HT and a small molecule acceptor," Thin Solid Films, vol. 517, no. 24, pp. 6833-6836, 2009. 
[15] H. Y. Lu, B. Akgun, and T. P. Russell, "morphological characterization of a low-bandgap crystalline polymer: PCBM bulk heterojunction solar cells," Advanced Energy Materials, vol. 1, no. 5, pp. 870-878, 2011.

[16] S.-Y. Ma, Y.-M. Shen, P.-C. Yang, C.-S. Chen, and C.-F. Lin, "Morphological modification induced by external electric field during solution process of organic solar cells," Organic Electronics, vol. 13, no. 2, pp. 297-301, 2012.

[17] W. Ma, C. Yang, X. Gong, K. Lee, and A. J. Heeger, “Thermally stable, efficient polymer solar cells with nanoscale control of the interpenetrating network morphology," Advanced Functional Materials, vol. 15, no. 10, pp. 1617-1622, 2005.

[18] D. E. Markov, C. Tanase, P. W. M. Blom, and J. Wildeman, "Simultaneous enhancement of charge transport and exciton diffusion in poly(p-phenylene vinylene) derivatives," Physical Review B, vol. 72, no. 4, Article ID 045217, 2005.

[19] J. J. M. Halls, K. Pichler, R. H. Friend, S. C. Moratti, and A. B. Holmes, "Exciton diffusion and dissociation in a poly(p-phenylenevinylene)/C60 heterojunction photovoltaic cell," Applied Physics Letters, vol. 68, no. 22, pp. 3120-3122, 1996.

[20] S. Cook, A. Furube, and R. Katoh, "Analysis of the excited states of regioregular polythiophene P3HT," Energy and Environmental Science, vol. 1, no. 2, pp. 294-299, 2008.

[21] J. Yu, J. Huang, H. Lin, and Y. Jiang, "Exciton diffusion length analysis of mixed donor materials in organic solar cells by doping with phosphorescent iridium complex," Journal of Applied Physics, vol. 108, no. 11, Article ID 113111, 6 pages, 2010.

[22] A. Tsuboyama, H. Iwawaki, M. Furugori et al., "Homoleptic cyclometalated iridium complexes with highly efficient red phosphorescence and application to organic light-emitting diode," Journal of the American Chemical Society, vol. 125, no. 42, pp. 12971-12979, 2003.

[23] Z. Xu, B. Hu, and J. Howe, "Improvement of photovoltaic response based on enhancement of spin-orbital coupling and triplet states in organic solar cells," Journal of Applied Physics, vol. 103, no. 4, Article ID 043909, 6 pages, 2008.

[24] G. Winroth, D. Podobinski, and F. Cacialli, "Dopant optimization for triplet harvesting in polymer photovoltaics," Journal of Applied Physics, vol. 110, no. 12, Article ID 124504, 6 pages, 2011.

[25] B. P. Rand, S. Schols, D. Cheyns et al., "Organic solar cells with sensitized phosphorescent absorbing layers," Organic Electronics, vol. 10, no. 5, pp. 1015-1019, 2009.

[26] C.-L. Lee, I.-W. Hwang, C. C. Byeon, B. H. Kim, and N. C. Greenham, "Triplet exciton and polaron dynamics in phosphorescent dye blended polymer photovoltaic devices," Advanced Functional Materials, vol. 20, no. 17, pp. 2945-2950, 2010.

[27] W. Zhang, Y. Xu, H. Wang, C. Xu, and S. Yang, " $\mathrm{Fe}_{3} \mathrm{O}_{4}$ nanoparticles induced magnetic field effect on efficiency enhancement of P3HT:PCBM bulk heterojunction polymer solar cells," Solar Energy Materials and Solar Cells, vol. 95, no. 10, pp. 2880-2885, 2011.

[28] R. A. Janssen and J. Nelson, "Factors limiting device efficiency in organic photovoltaics," Advanced Materials, vol. 25, no. 13, pp. 1847-1858, 2013.

[29] J. Wang, F. J. Zhang, B. Liu, Z. Xu, J. Zhang, and Y. S. Wang, "Emission colour-tunable phosphorescent organic lightemitting diodes based on the self-absorption effect and excimer emission," Journal of Physics D, vol. 46, no. 1, Article ID 015104, 7 pages, 2013.

[30] Y. Zeng, L. Biczok, and H. Linschitz, "External heavy atom induced phosphorescence emission of fullerenes: the energy of triplet C60," Journal of Physical Chemistry, vol. 96, no. 13, pp. 5237-5239, 1992.

[31] Z. X. Wang, F. J. Zhang, J. Wang et al., "Organic photovoltaic cells: novel organic semiconducting materials and molecular arrangement engineering," Chinese Science Bulletin, vol. 57, no. 32, pp. 4143-4152, 2012.

[32] Z. Y. Zhao, L. Rice, H. Efstathiadis, and P. Haldar, “Thickness dependent effects of thermal annealing and solvent vapor treatment of poly (3-hexylthiophene) and fullerene bulk heterojunction photovoltaics," Photovoltaic Materials and Manufacturing Issues, vol. 1123, pp. 171-178, 2009.

[33] Z.-L. Zhuo, F.-J. Zhang, X.-W. Xu, J. Wang, L.-F. Lu, and Z. $\mathrm{Xu}$, "Photovoltaic performance improvement of P3HT:PCBM polymer solar cells by annealing treatment," Acta PhysicoChimica Sinica, vol. 27, no. 4, pp. 875-880, 2011.

[34] F. Zhang, Z. Zhuo, J. Zhang et al., "Influence of PC60BM or PC70BM as electron acceptor on the performance of polymer solar cells," Solar Energy Materials and Solar Cells, vol. 97, pp. 71-77, 2012. 

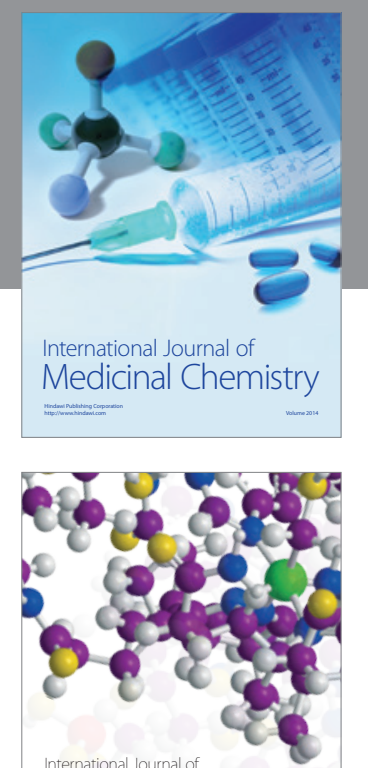

\section{Carbohydrate} Chemistry

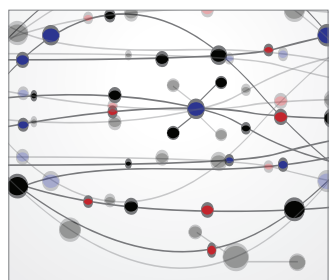

The Scientific World Journal
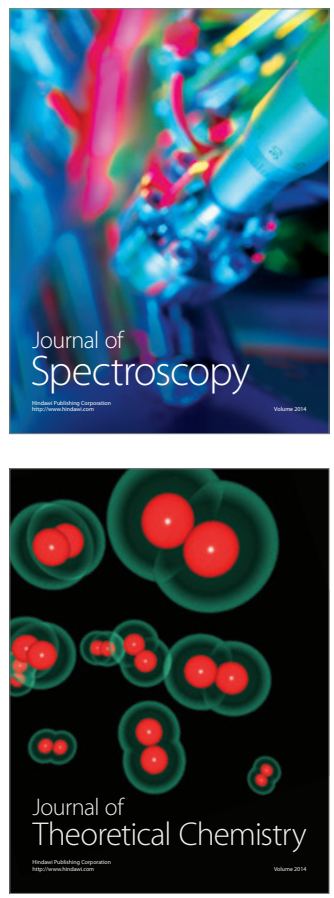
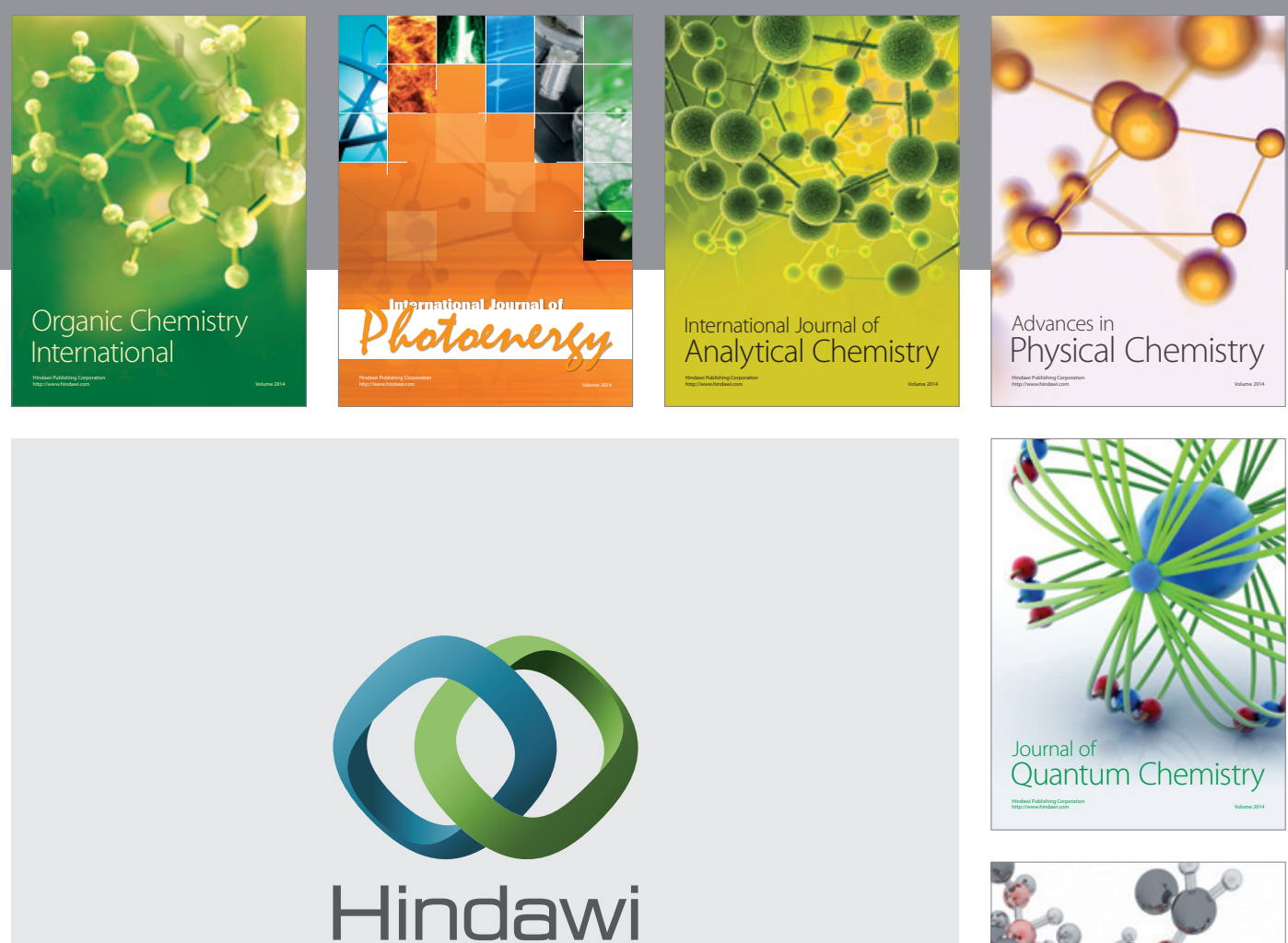

Submit your manuscripts at

http://www.hindawi.com

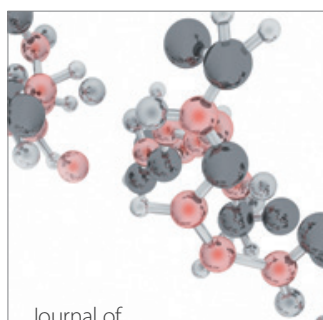

Analytical Methods

in Chemistry

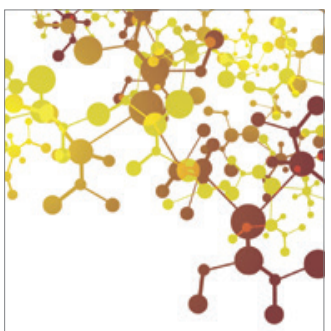

Journal of

Applied Chemistry

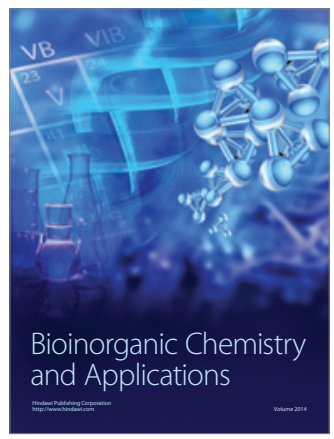

Inorganic Chemistry
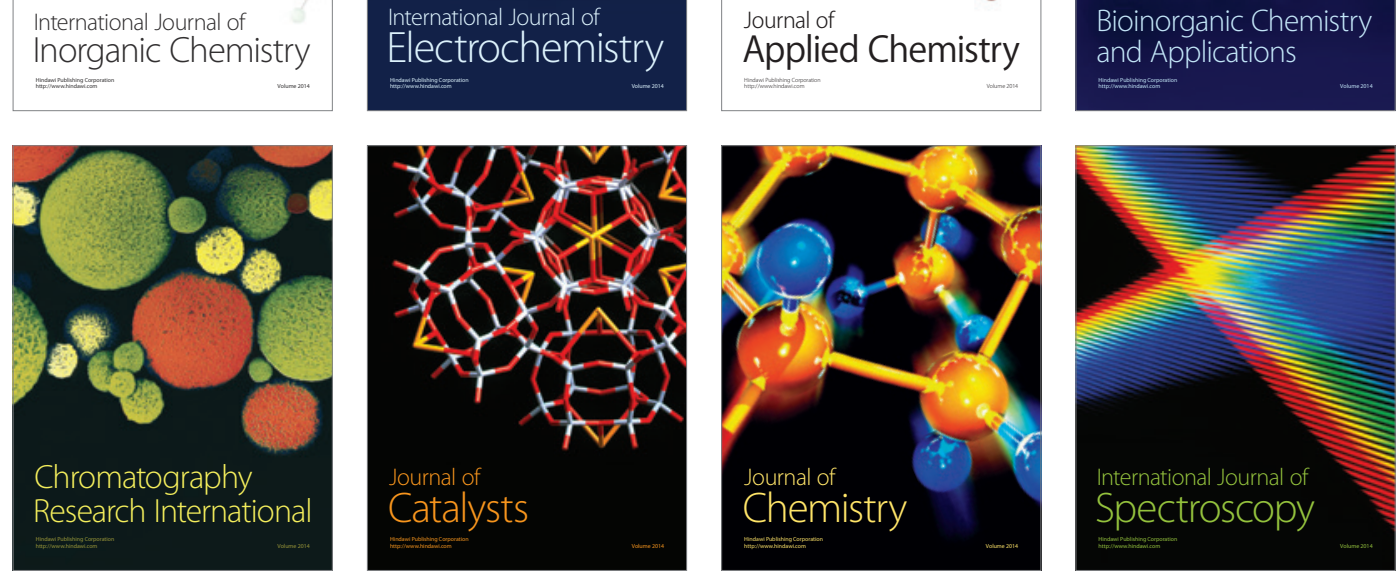